\title{
Automatyzacja i robotyzacja procesu montażu i spawania profili walcowanych - część 1 - historia
}

\author{
Automation and robotics \\ of assembly and welding processes of rolled sections \\ - part one - history
}

\begin{abstract}
Streszczenie
W artykule przedstawiono krótką historię robotyzacji, od prostych urządzeń automatycznych do skomplikowanych robotów przemysłowych. Podano podstawowe informacje dotyczące budowy zrobotyzowanych linii produkcyjnych oraz wykorzystanych w nich urządzeń z zakresu różnych dziedzin nauki i techniki. Opisano budowę robotów, zasady działania i sterowania nimi z naciskiem na roboty przemysłowe, głównie spawalnicze. Publikacja jest wstępem do kolejnego artykułu opisującego pionierskie urządzenie do zrobotyzowanego montażu i spawania profili walcowanych Steel Beam Assembler of Welder (SBA) firmy Zeman \& Co.
\end{abstract}

Słowa kluczowe: robot, robotyzacja, proces spawania

\section{Abstract}

The article presents a brief history of robotics from the simple automatic devices to the complex industrial robots. It contains the basic information relating to the structure of robotized production lines, and devices used from different science and technique areas. It describes a structure of robots, rules of operation and control, mainly industrial robots, especially welding. It is an introduction to another article which depicts a pioneering device called Steel Beam Assembler of Welder (SBA) by Zeman \& Co company used to a robotized assembly and welding of rolled sections.

Keywords: robot, robotics, welding process

\section{Wstęp}

W dobie rosnącego poziomu konkurencji na rynku wzrasta zapotrzebowanie na nowoczesne rozwiązania zwiększające produktywność przedsiębiorstw i umożliwiające wytwarzanie produktów o jak najwyższej jakości przy jak najniższym zużyciu materiałów i w jak najkrótszym czasie. Jest to spowodowane rosnącymi wymaganiami jakościowymi projektowanych konstrukcji, jak i optymalizacją procesów wytwarzania oraz kontroli jakości produkcji. Rozwiązaniem, które może sprostać tym wymaganiom i spełnić powyższe warunki, jest robotyzacja procesów produkcyjnych, czyli zastępowanie funkcji intelektualnych, fizjologicznych i energetycznych ludzi - pracą robotów przemysłowych [1].

Dr hab. inż. Jacek Słania, prof. PCz - Politechnika Częstochowska, mgr inż. Roman Dziędzioł - ZEKON Sp. z o.o. Ruda Śląska. 
Gałęzią przemysłu, która stawia robotyzacji wysokie wymagania, jest spawalnictwo. Nie chodzi tutaj o wykonywanie prostych powtarzalnych czynności, jak chociażby zgrzewanie w motoryzacji, czy spawanie np. blachownic, które ogranicza się przeważnie do jednej pozycji spawania, takimi samymi parametrami, ale o kompleksowe wykorzystanie wszystkich możliwości, jakie niesie ze sobą robotyzacja. Mowa tu o urządzeniach, które są w stanie samodzielnie bez pomocy człowieka uzbroić i pospawać skomplikowane elementy konstrukcji stalowych. Rola człowieka ogranicza się $\mathrm{w}$ tym przypadku jedynie do programowania i obsługi urządzenia. W tej materii dopiero raczkujemy, a związane jest to z problemami, jakie napotykają konstruktorzy tych maszyn. Problemy te to przede wszystkim ogromna różnorodność produkowanych profili walcowanych (od dwuteowników przez profile zamknięte do rur), a także skomplikowane rozwiązania narzucane przez projektantów konstrukcji stalowych.

\section{Gałęzie techniki wykorzystywane w maszynach do automatycznego uzbrojenia i spawania profili stalowych}

Zakres dziedzin nauki i gałęzi techniki wykorzystywanych do budowania, a także funkcjonowania urządzeń do automatycznego uzbrojenia i spawania profili stalowych łączy w sobie całą gamę najnowszych, a także sprawdzonych rozwiązań z różnych obszarów wiedzy od mechaniki, automatyki poprzez elektronikę do informatyki.

Zbudowanie tak złożonych i wszechstronnych maszyn wymaga współpracy wielu zespołów specjalistów z różnych dyscyplin nauki, którzy swoją wiedzę popierają ogromnym doświadczeniem. Nie należy przy tym zapomnieć o znajomości zagadnień z dziedziny ekonomii, które powinny stanowić podstawę całego przedsięwzięcia.

Budowa tego typu urządzeń wykorzystuje w szerokim zakresie różnego rodzaju elementy, zespoły oraz układy automatyczne, do których należą:

a) elementy i układy wykonawcze wprawiające w ruch mechanizmy maszyn, np.:

- siłowniki elektryczne (liniowe bądź wahadłowe) zbudowane z silnika elektrycznego oraz redukcyjnej przekładni zębatej,

- siłowniki pneumatyczne wykorzystujące energię sprężonego powietrza,siłowniki hydrauliczne napędzane energią cieczy pod ciśnieniem;

b) zawory sterujące i rozdzielające stosowane do regulacji i utrzymywania wymaganej wartości ciśnienia $w$ instalacji lub w konkretnym odbiorniku, a także do sterowania kierunkiem przepływu powietrza do odpowiednich komór siłownika; c) systemy sensoryczne informujące o położeniu, przemieszczaniu i ruchu maszyny lub urządzenia, które mają za zadanie przetworzyć bodźce zewnętrzne na mierzalny sygnał elektryczny. Możemy tu wyróżnić czujniki obecności, położenia, ciśnienia, przepływu, prędkości, siły itp.;

d) systemy skanujące i wizyjne mające zastosowanie m.in. do rozpoznawania kształtu elementów (np. blach), sprawdzania kompletności montażu, odczytywania kodów kreskowych, nadzoru nad procesem produkcji itd.;

e) elementy informacyjne i wskaźnikowe służące do komunikowania się operatora z urządzeniem. Należą do nich:

- sygnalizatory świetlne i dźwiękowe,

- wyświetlacze cyfrowe,

- wyświetlacze alfanumeryczne,

- terminale tekstowe,

- terminale graficzne,

- monitory komputerowe,

f) urządzenia sterujące, czyli układy, w których przetwarzane są polecenia (informacje) na sygnały zarządzające i sterujące obiektami. Do tej grupy możemy zaliczyć:

- regulatory,

- Sterowniki PLC (programowalne sterowniki logiczne), których podstawą działania jest cyklicznie realizowany program pracy sterownika.

- sterowniki komputerowe [2].

Aby wszystkie ww. składniki mogły wspólnie funkcjonować, całość musi być powiązana ze sobą najważniejszym elementem, czyli potężnym oprogramowaniem komputerowym. W całość wkomponowana jest wiedza i technologia spawalnicza, która musi sprostać ostrym i sprecyzowanym w odpowiednich normach wymaganiom.

Stworzenie tak złożonych urządzeń jest możliwe tylko dzięki połączeniu i dogłębnej znajomości wielu gałęzi nauki i techniki, czyli: inżynierii przemysłowej, informatyki, fizyki i matematyki, elektryczności, mechaniki i ekonomii.

\section{Robotyka}

Robotyka jest interdyscyplinarną dziedziną wiedzy technicznej, która zajmuje się budową robotów, proich gramowaniem, sterowaniem i zastosowaniem w praktycznie każdej dziedzinie działalności ludzkiej - od przemysłu, medycyny, administracji - poprzez transport, usługi, rolnictwo, budownictwo, aż do celów wojskowych i podboju przestrzeni kosmicznej [3].

Robotyka jest dziedziną nauki wykorzystującą wiedzę z takich dyscyplin jak teoria sterowania, teoria decyzji, teoria sygnałów i systemów, telekomunikacja, informatyka, mechanika, elektronika i mechatronika, problematyka sterowania, inteligencja maszynowa, projektowanie i zastosowanie manipulatorów oraz robotów. 
Robotykę można podzielić na dwie grupy:

- robotykę ogólną, która obejmuje zagadnienia ekonomiczne, społeczne, ochrony i bezpieczeństwa pracy, terminologii i oznaczeń, a także perspektywy rozwoju;

- robotykę teoretyczną (teorię manipulatorów i robotów), dotyczącą układów napędowych, mechanicznych, sensorycznych, sterowania i programowania [3].

Podstawowe pojęcia $\mathrm{w}$ robotyce to manipulator i robot. Manipulatorem nazywamy mechanizm przeznaczony do realizacji niektórych funkcji kończyn górnych człowieka spełniający funkcję manipulacyjną realizowaną przez chwytak i wysięgnikową wykonywana przez ramię manipulatora. Natomiast robotem według Encyklopedii Powszechnej PWN nazywane jest „urządzenie (maszyna) przeznaczone do realizacji niektórych czynności manipulacyjnych, lokomocyjnych, informatycznych i intelektualnych człowieka [4]."

\section{Historia rozwoju robotyki}

Według przekazów historycznych już w starożytności pojawiły się pierwsze automaty. W pierwszym wieku p.n.e. Archytas z Tarentu wykonał kilka zabawek mechanicznych, m.in. mechanicznego gołębia, który podobno potrafił latać.

W średniowieczu budowano różnego rodzaju mechanizmy napędzane energią przepływającej wody, czy też siłą ciężkości. Powstawały wtedy ruchome figury przypominające wyglądem człowieka i naśladujące niektóre jego funkcje, np. otwieranie drzwi, bądź witanie wchodzących.

Później zaczęto budować coraz bardziej skomplikowane maszyny, wykorzystując energię zmagazynowaną w sprężynach, przekazywaną przez koła zębate do elementów wykonujących odpowiednie zadania, np. do zegarów poruszających figurkami.

Słowo "robot" pojawiło się pierwszy raz w dramacie fantastyczno-naukowym z 1920 r „R.U.R. - Rossum's Universal Robots". Autor Karel Capek terminem tym nazwał maszynę (istotę) zastępującą człowieka w najbardziej uciążliwych pracach [3].

Początek XX w. przyniósł prace nad robotami człekokształtnymi z wykorzystaniem elektryczność (silników napędowych, mikrofonów, głośników, fotokomórek), które mogły wykonywać proste polecenia.

Przemysłowe zastosowanie, a więc początek robotyki przemysłowej datuje się na rok 1947, kiedy to w Stanach Zjednoczonych zbudowano pierwszy teleoperator z serwonapędami elektrycznymi. Natomiast pierwszy programowalny robot został zbudowany w 1954 r. przez George'a Devola. Prawa do robota Devola zakupił Joseph Engelberger i założył pierwszą na świecie firmę produkującą roboty Unimation Company. Roboty firmy Engelbergera pojawiły się w przemyśle samochodowym w 1961 r., gdzie znalazły zastosowanie do obsługi ciśnieniowej maszyny odlewniczej w firmie General Motors [2].

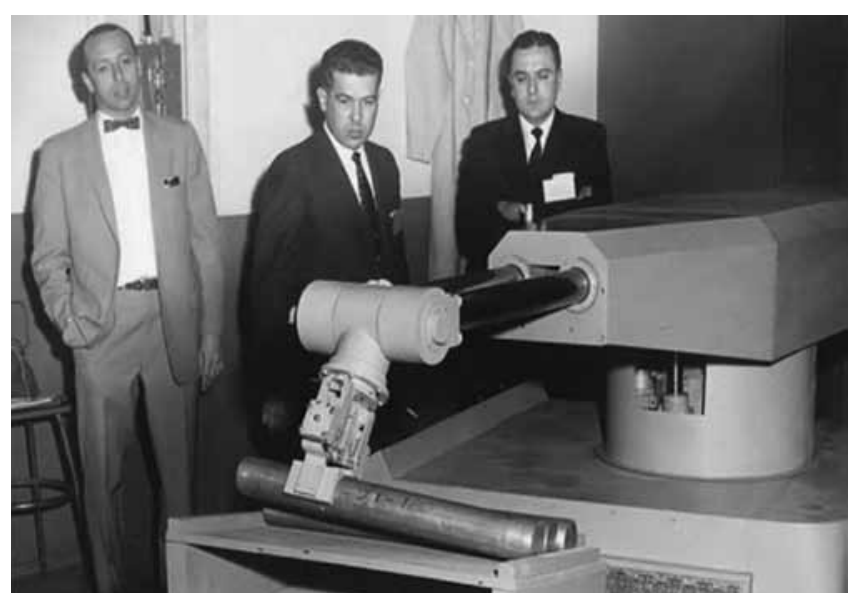

Rys. 1. Unimate - pierwszy na świecie robot przemysłowy (opracowany przez G. Devola, J. Engelbergera)

Fig. 1. Unimate - the first industrial robot in the world (designed by G. Devol, J. Engelberger)

W końcu lat 60 ub.w. powstały pierwsze ośrodki badawcze i fabryki robotów w Europie i Japonii. Od tego czasu trwały intensywne prace rozwojowe nad systemami sterowania, kinematyką robotów, komunikacją, powstały pierwsze języki programowania. Zastosowanie tranzystorów spowodowało gwałtowny rozkwit takich dziedzin nauki jak elektronika i informatyka, a to w ogromnym stopniu wpłynęło na tempo rozwoju robotyki. Prace rozwojowe i różnorodność zastosowań robotów spowodowała, że dyscyplina nauki ulegała i w dalszym ciągu ulega coraz większej specjalizacji i podziałom. Głównym kryterium podziału wg portalu asimo.pl jest sposób wykorzystania robotów. Pod tym względem dzieli się je na:

- roboty eksperymentalne i badawczo - rozwojowe,

- roboty wojskowe i policyjne,

- roboty do użytku osobistego i w domu,

- roboty do użytku publicznego,

- roboty eksploracyjne, poszukiwawcze i kosmiczne,

- roboty do rozrywki, zabawki i edukacyjne,

- roboty społeczne, osobiste, interaktywne i terapeutyczne,

- zrobotyzowane środki transportu, autonomiczne samochody,

- roboty medyczne i okołomedyczne,

- roboty przemysłowe [5].

Warto w tym miejscu wspomnieć o generacjach robotów, które związane są z rozwojem robotyki. Można wyróżnić trzy generacje:

- Roboty I generacji (nauczane), które mają własną programowalną pamięć i pracują ściśle według zadanych rozkazów. Charakteryzują się brakiem samodzielności, nie mają sprzężeń zwrotnych.

- Roboty II generacji (uczące się), które dzięki zastosowaniu czujników i systemów wizyjnych potrafią rozróżniać kształty i położenia obiektów. Mają sprzężenie zwrotne, dzięki czemu reagują na zmiany w otoczeniu robota.

- Roboty III generacji (inteligentne) są wyposażone $w$ różnego rodzaju analizatory, które dokonują pomiarów parametrów otoczenia i za pomocą 
tzw. sztucznej inteligencji mają możliwość adaptacji do zmieniających się warunków (ciągłe aktualizowanie programu pracy).

\section{Roboty w przemyśle}

Spośród wymienionych w poprzednim rozdziale grup robotów najważniejsze są roboty przemysłowe, które są największą i najistotniejszą grupą nie tylko ze względu na ilość i różnorodność zastosowań, ale także z punktu widzenia ekonomii i gospodarki.

Według PN_EN ISO8373:2001: „Manipulacyjny robot przemysłowy jest automatycznie sterowaną, programowaną, wielozadaniową maszyną manipulacyjną o wielu stopniach swobody, posiadającą własności manipulacyjne lub lokomocyjne, stacjonarną lub mobilną, dla ważnych zastosowań przemysłowych [6]."

W literaturze można spotkać różne ujęcia klasyfikacji robotów przemysłowych, np. ze względu na rodzaj budowy, sterowania, mobilność, precyzję pozycjonowania itd. Poniżej przedstawiono ogólny schemat podziału robotów przemysłowych ze względu na strukturę kinematyczną.

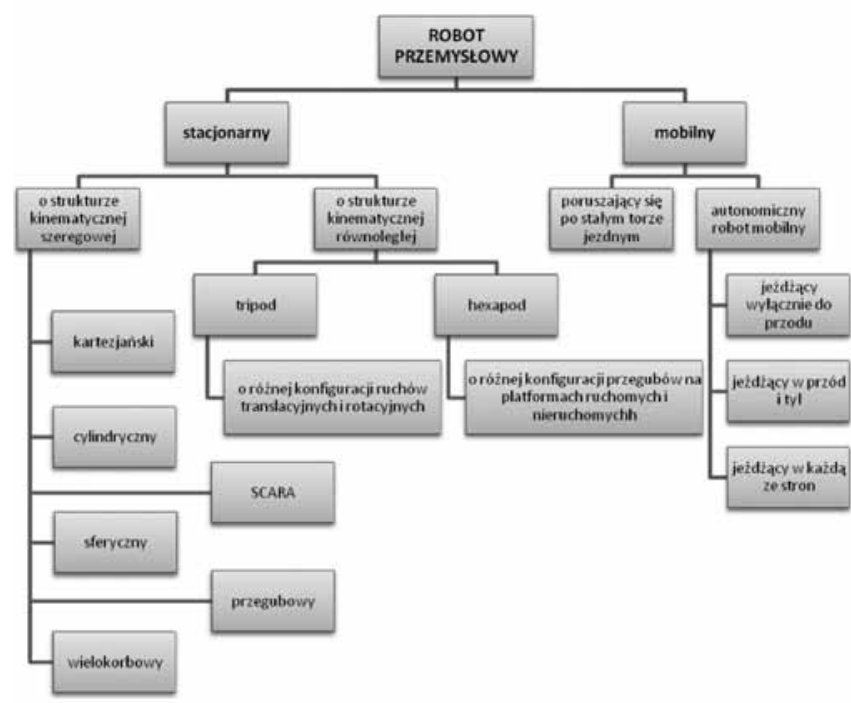

Rys. 2. Klasyfikacja robotów przemysłowych ze względu na strukturę kinematyczną [3]

Fig. 2. Classification of industrial robots due to a kinematic structure [3]

Pokazany schemat jest bardzo ważny ze względu na kinematykę, która jest jednym z podstawowych zagadnień zastosowań i budowy robotów.

Ogólną budowę robota przemysłowego wyróżnia:

- część mechaniczna (manipulator), czyli ramię lub układ kilku ramion,

- napędy ramion robota,

- układ sterowania (komputer sterujący),

- oprzyrządowanie ramienia (narzędzia),

- sensory (czujniki),

- zewnętrzne źródło zasilania.

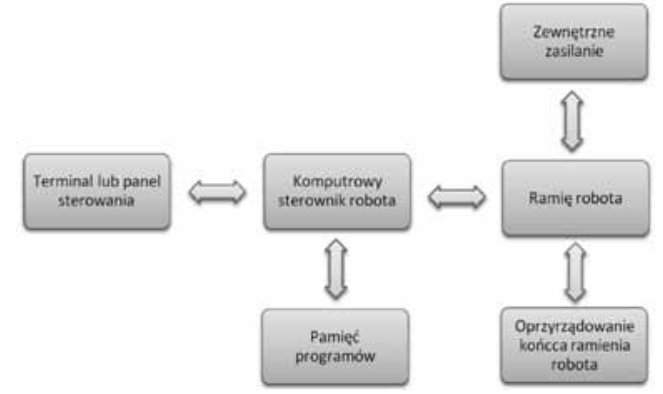

Rys. 3. Schemat blokowy robota przemysłowego

Fig. 3. A block diagram of an industrial robot

Do parametrów decydujących o możliwościach zastosowania robotów w przemyśle możemy zaliczyć:

- liczbę osi,

- liczbę stopni swobody,

- przestrzeń roboczą,

- kinematykę,

- udźwig robota,

- prędkości i przyspieszenia mechanizmów,

- powtarzalność i dokładność pozycjonowania,

- kontrolę trajektorii ruchu,

- źródło energii napędów,

- niezawodność,

- podatność statyczną na obciążenia.

Parametry te są brane pod uwagę podczas konstruowania robotów w zależności od ich przeznaczenia, które jest bardzo szerokie i obejmuje wszystkie gałęzie przemysłu. Można tu wymienić m.in. roboty spawalnicze, montażowe, pakujące, paletyzujące, malarskie, do obróbki materiałów, do manipulowania obiektami, do załadunku i owijania palet, transportujące, roboty do utylizacji i zabezpieczania odpadów przemysłowych, dozujące i napełniające, inspekcyjne, testujące itd.

Szybki rozwój automatyzacji w przemyśle jest bardzo mocno związany $z$ robotyzacją systemów wytwarzania. Zrobotyzowany system wytwarzania można przedstawić jako zbiór powiązanych ze sobą podsystemów składowych (rys. 4), takich jak: podsystem sterowania, kontroli i diagnostyki, technologiczny, transportu, magazynowania, robot jako podsystem manipulacji oraz podsystem oprzyrządowania (chwytaki, narzędzia) [3].

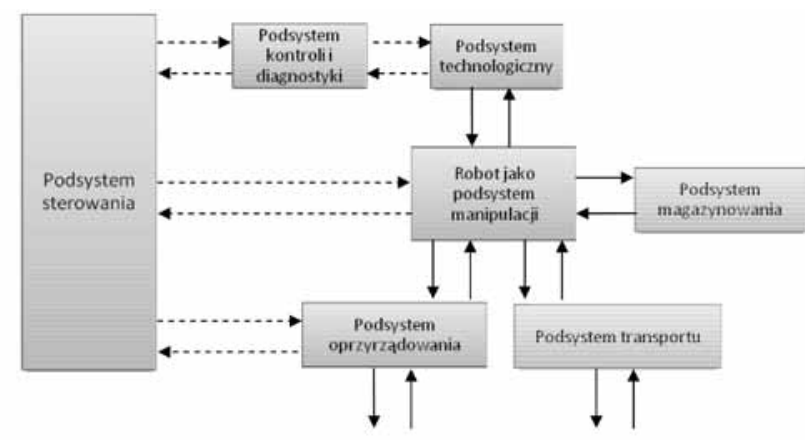

Przepływ informacji $\rightarrow$

Przepływ materiałów $\longrightarrow$

Rys. 4. Struktura funkcjonalna systemów wytwarzania [3]

Fig. 4. A functional structure of production systems [3] 
Powyższy schemat jest ogólnym przedstawieniem powiązań między poszczególnymi podsystemami tworzącymi całość systemów wytwarzania i pokazuje zasadę budowy takich maszyn, jakim jest np. urządzenie do automatycznego uzbrajania i spawania profili stalowych SBA, które zostanie opisane w następnym artykule.

\section{Robotyzacja procesów spawania}

Spośród wszystkich gałęzi przemysłu robotyzacja najszerzej weszła do procesów spawalniczych. Powodem takiego stanu rzeczy jest poprawa wydajności, warunków pracy i jakości. Wzrost wydajności wynika z faktu, że robot w porównaniu do spawacza "nie męczy się", więc pracuje ciągle w takim samym tempie, czego efektem jest dużo większy współczynnik wykorzystania łuku elektrycznego (stosunek czasu jarzenia się łuku spawalniczego do czasu potrzebnego na wykonanie wszystkich spoin wyrażony w procentach), a także z prędkości przemieszczania się uchwytu spawalniczego między spoinami. Robot ma łatwiejszy dostęp do spoin, a co za tym idzie nie ma konieczności przezbrajania stanowiska. Oprócz tego zapewnia stabilną jakość wykonania spoin. Robotyzacja procesu pozwala także ograniczyć zagrożenia, na jakie są narażeni spawacze, czyli emisję szkodliwych gazów, par metali, promieniowanie, hałas, poparzenia itp. Kolejnym atutem zastosowania robotów jest zwiększenie konkurencyjności, innowacyjności i prestiżu przedsiębiorstwa.

Najczęstszymi metodami stosowanymi w zrobotyzowanych technikach spawalniczych są:

- spawanie łukowe,

- zgrzewanie oporowe,

- przecinanie plazmowe i laserowe.

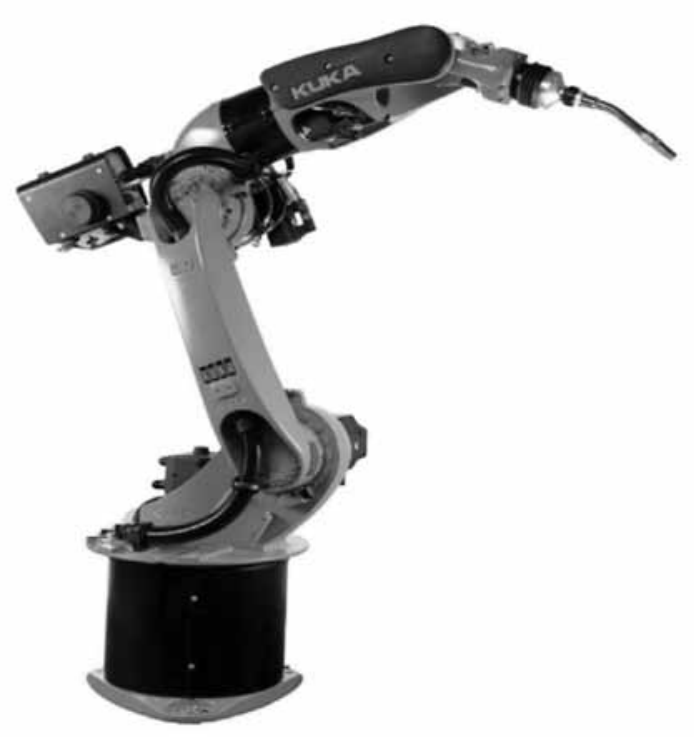

Rys. 5. Robot spawalniczy KUKA KR16 HW

Fig. 5. Welding robot KUKA KR16 HW
W przypadku spawania łukowego najczęściej wykorzystuje się spawanie łukowe elektrodą topliwą w osłonie gazowej MIG (Metal Inert Gas), MAG (Metal Aktive Gas), oraz spawanie łukowe elektrodą nietopliwą w osłonie gazu obojętnego TIG (Tungsten Inert Gas). Metody te ze względu na swój charakter pozwalają w stosunkowo prosty sposób zrobotyzować proces spawania, gdyż nie jest konieczne zamontowanie na ramionach robota całej ciężkiej spawarki, lecz jedynie lekkiego palnika, połączonego z resztą urządzenia za pomocą elastycznych przewodów [8].

W zależności od zadania technicznego każde zrobotyzowane stanowisko do spawania ma inny indywidualny charakter, ale można przyjąć pewien schemat budowy, który jest oparty na następujących elementach:

- robot przemysłowy,

- pozycjoner (urządzenie pozycjonująco - manipulacyjne),

- źródło prądu,

- podajnik drutu [3].

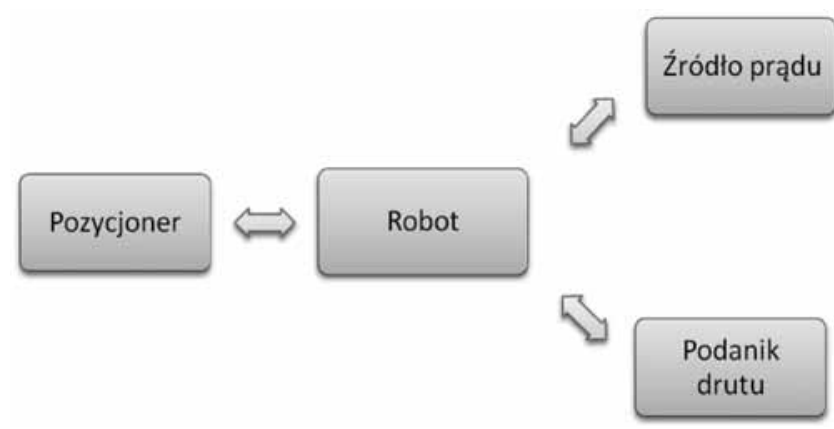

Rys. 6. Schemat blokowy zrobotyzowanego stanowiska spawalniczego Fig. 6. A block diagram of a robotized welding place

Roboty stosowane do celów spawalniczych są to najczęściej roboty przegubowe o sześciu stopniach swobody, które powinny mieć następujące funkcje wykorzystywane $\mathrm{w}$ procesie spawania:

- Możliwość różnych wzorów ruchów oscylacyjnych, niezbędnych do wykonywania szerokich spoin, zapisanych w pamięci robota.

- Ponowny zapłon łuku. W razie nieudanego zapłonu łuku robot automatycznie przesuwa się w zaprogramowanym kierunku i ponownie próbuje zapoczątkować łuk.

- Automatyczne uwalnianie przyspawanego drutu.

- Nakładanie spoiny. W przypadku wznawiania spawania robot automatycznie cofa się, uzyskując gładką ciągłą spoinę.

- Wznawianie pracy. W razie awarii zasilania jest zapamiętany dokładny stan robota, który po wznowieniu zasilania ponawia pracę dokładnie w miejscu jego zaniku.

- Automatyczne kalibrowanie palnika [3].

Ze względu na wysoki współczynnik wykorzystania sprzętu spawalniczego w zrobotyzowanym stanowisku dochodzący do 90\% musi on spełniać bardzo wysokie wymagania. 
Warto także wspomnieć przy okazji omawiania robotyzacji procesów spajania o zgrzewaniu oporowym, które ze względu na łatwość zrobotyzowania jest szeroko stosowane w produkcji, szczególnie w przemyśle samochodowym. Charakteryzuje się ono szybkością, dokładnością i możliwością wykonania zgrzeiny w dowolnym położeniu [9].

Dobrym przykładem zrobotyzowanego stanowiska spawalniczego jest linia produkcyjna do wytwarzania dwuteownika spawanego ze środnikiem falistym. Dwuteownik taki charakteryzuje się dużą nośnością przy stosunkowo niskim ciężarze własnym w porównaniu do typowych dwuteowników o podobnych parametrach wytrzymałościowych.

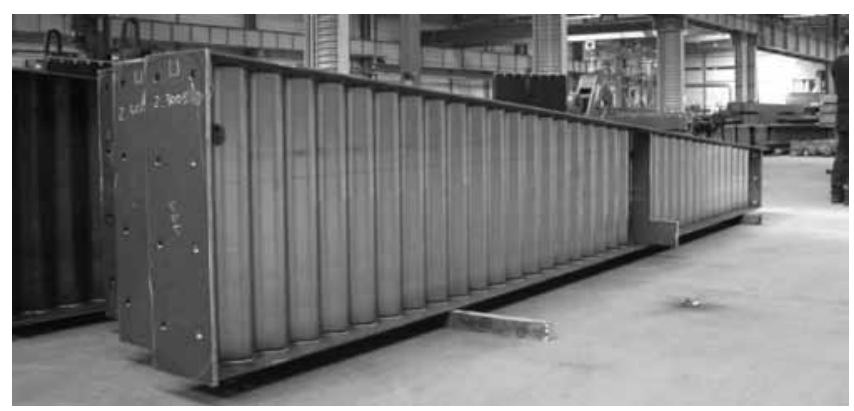

Rys. 7. Dwuteownik spawany ze środnikiem falistym [7] Fig. 7. Welded I-beam with a wavy web [7]

Chociaż idea takiego dwuteownika pojawiła się już dawno, to przez dłuższy czas nie znalazła praktycznego zastosowania ze względu na brak technologii wykonania. Dopiero zastosowanie robotów umożliwiło uruchomienie produkcji tego kształtownika.

Głównym problemem uniemożliwiającym zautomatyzowanie wykonania tego dwuteownika był brak technologii pozwalającej na płynne przejście pomiędzy pozycjami spawania podczas układania spoiny. Dzięki wykorzystaniu robota spawalniczego jest możliwe ciągłe spawanie w trzech pozycjach: PB (naboczna), PG (pionowa w dół) i PF (pionowa w górę).

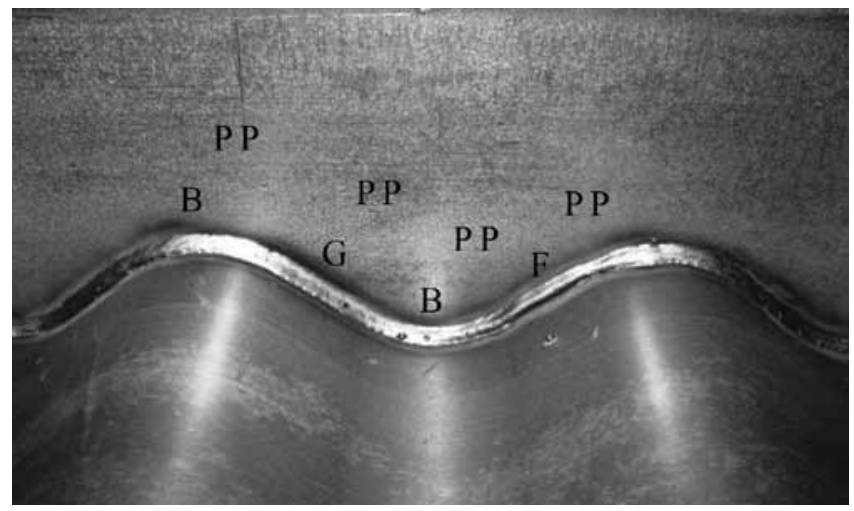

Rys. 8. Pozycje spawania [7]

Fig. 8. Positions of welding $[7]$

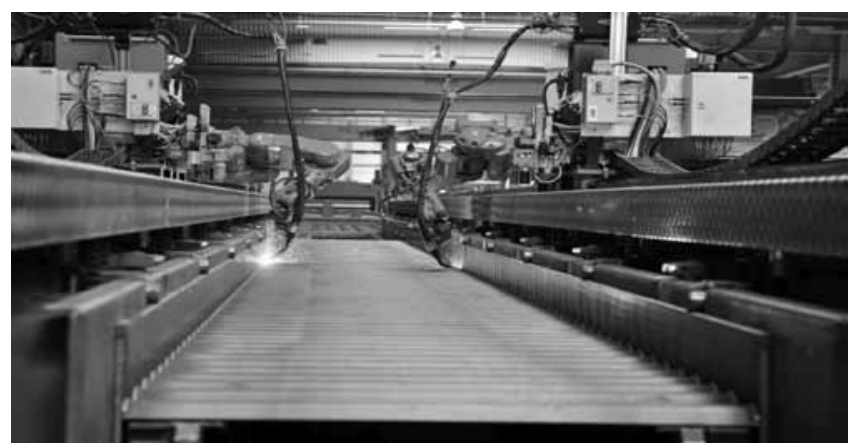

Rys. 9. Proces spawania dwuteownika ze środnikiem spawanym [7] Fig. 9. Welding process of an I-beam with a welded web [7]

Wykorzystanie robota spawalniczego (IRB-140 firmy ABB) w połączeniu ze źródłem prądu (Trans Puls Synergic 5000 firmy Fronius) regulującym cały proces spawania umożliwiło zbudowanie urządzenia wytwarzającego dwuteowniki ze środnikiem spawanym.

\section{Podsumowanie}

Jak więc widać, robotyzacja procesów spawalniczych wpływa nie tylko na zwiększenie wydajności, jakości czy polepszenie warunków pracy, ale także pozwala wejść w nowe, do tej pory nieosiągalne obszary produkcji.

\section{Literatura}

[1] Łapiński K., Peterlik M., Wyżnikiewicz B.: Wpływ robotyzacji na konkurencyjność polskich przedsiębiorstw, Instytut Badań nad Gospodarką Rynkową, Warszawa 2013.

[2] Klimsara W.J., Pilat Z.: Podstawy automatyki i robotyki, Wydawnictwa Szkolne i Pedagogiczne S.A., Warszawa 2006.

[3] Honczarenko J.: Roboty przemysłowe. Budowa i zastosowanie, Wydawnictwa Naukowo-Techniczne, Warszawa 2004.

[4] Encyklopedia Powszechna PWN, Warszawa 1987.

[5] http://www.asimo.pl/materialy/download/robotyka_roboty_podzial.pdf dn. 07.02.2014 r.

[6] Norma PN-EN ISO 8373:2001 Roboty przemysłowe - Terminologia.

[7] Materiały źródłowe firmy Zekon Sp. z o.o.

[8] Nowak M., Buchowski J., Wiśniewski D.: Zrobotyzowane spawanie wielkogabarytowych elementów ze wspomaganiem oprogramowania off-line. Przegląd Spawalnictwa 2013, nr 10, s. 19-29.

[9] Stania J., Kuk Ł.: Proces łączenia materiałów do budowy pojazdów i nadwozi w przemyśle samochodowym. Przegląd Spawalnictwa 2014, nr 3, s. 40-46. 